\title{
O leksyce i frazeologii \\ Dyszkursu o grzechách szostego przykazánia Bożego... Adama Gdacjusza
}

\author{
On Lexis and Phraseology \\ in Adam Gdacjusz' Dyszkurs o grzechách szostego przykazánia Bożego...
}

Słowa klucze: leksyka i frazeologia, Adam Gdacjusz, kaznodziejstwo, polszczyzna śląska Key words: lexis and phraseology, Adam Gdacjusz, preaching, Silesian Polish

Kaznodzieja kluczborski Adam Gdacjusz¹, a właściwie Gdak, był jedną z ciekawszych postaci $w$ historii śląskiej literatury XVII wieku. To, co wyróżniało go spośród innych pastorów i pisarzy, to z pewnością język, za którego pomocą przekazywał swoje poglądy, przemyślenia, rady i uwagi. Język był dla niego narzędziem, jakim posługiwał się znakomicie w komunikacji z parafianami oraz słuchaczami jego kazań i nauk. Kompetencje językowe wypływały z ogromnego oczytania, szczególnie w twórczości pisarzy wieku $\mathrm{XVI}^{2}$, oraz wykształcenia, które Gdacjusz pobierał $w$ Toruniu. Chociaż nigdy nie ukończył studiów, co stanowiło dla niego temat przykry i drażliwy, uważał siebie za osobę inteligentną, dorównującą wiedzą tym, których stać było na zgłębianie różnorakich nauk

\footnotetext{
* e-mail: a.haas@instytutslaski.com

1 Adam Gdacjusz (Gdacius), którego nazwisko brzmiało pierwotnie Gdak lub Gdaka, urodził się w 1609 lub 1610 roku w Kluczborku, a zmarł 7 kwietnia 1688 roku, także w tym mieście. Wywodził się z kluczborskiego pospólstwa miejskiego. Jego nazwiska nie ma wśród znanych śląskich rodzin pastorskich. Uczył się $w$ gimnazjum toruńskim, by później podjąć pracę jako nauczyciel w szkołach luterańskich. Zanim na dobre osiadł $w$ Kluczborku, przebywał w Spiskim Podgrodziu, w Bardiowie, $w$ Elblągu oraz $w$ Wilnie, skąd powrócił $w$ rodzinne strony. 8 września 1642 roku ożenił się $w$ Kluczborku z Marianną Skopówną, córką Tomasza Skopiusza, pastora w Ludwigsdorfie (dziś Nagodowice), a w 1648 roku urodził mu się syn (zob. ZarembA, 1969: 10-23; KACzMArzyK, 2003: 49-69).

${ }^{2}$ Kaznodzieja kluczborski wielokrotnie odwoływał się do twórczości takich pisarzy, jak Jan Kochanowski, Mikołaj Rej czy Marcin Kromer. W jego utworach możemy odnaleźć również bezpośrednie odniesienia do (lub cytaty z) tekstów autorstwa m.in. Jakuba Wujka, Łukasza Górnickiego, Jana Długosza, Marcina Bielskiego, Mikołaja Kochanowskiego (brata Jana Kochanowskiego), a także współczesnych mu twórców, np. Szymona Starowolskiego czy Krzysztofa Opalińskiego. Gdacjusz nawiązywał nadto do pisarzy protestanckich: arian - Szymona Budnego i Grzegorza z Żarnowca, luteranów - Andrzeja Schoenflissiusa i Samuela Dąbrowskiego, oraz kalwina - Krzysztofa Kraińskiego.
} 
na uniwersytetach. Umiłowanie literatury polskiej świadczyło o silnych z nią więziach śląskiego protestanta.

Gdacjusz jako pastor i kaznodzieja był szczerze i mocno zaangażowany $w$ życie duchowe, ale przede wszystkim $w$ życie ziemskie swoich podopiecznych. Wiedział, że słowem może zdziałać wiele, trafiając do jak najszerszego grona odbiorców - zazwyczaj ludzi prostych i niewykształconych. Jego teksty, które - zanim zostały wydrukowane - były wygłaszane z ambony podczas nabożeństw, niosły jasny, prosty przekaz o prawdach teologicznych i sprawach moralnych.

Wyjątkowość tekstów kluczborskiego „fararza” tkwi w niezwykłości doboru słownictwa i frazeologii, nierzadko z warstwy gwarowej - śląskiej³. Jego życie i twórczość przypadały na czasy trudne i zagmatwane, obfitujące w przeciwności natury politycznej. „Politycznie oderwany od Polski, od roku 1526 do korony habsburskiej należący Śląsk znalazł się w XVII wieku w ogniu zmagań i walk religijnych, określanych mianem kontrreformacji" (BOREK, 1962: 5). Możliwość twórczego działania zapewniło Gdacjuszowi zawarcie w 1648 roku pokoju westfalskiego, na którego mocy księstwa legnickie, brzeskie i oleśnickie (oraz miasto Wrocław) miały zagwarantowaną wolność wyznania luterańskiego. Kluczbork miejsce posługi duszpasterskiej protestanckiego kaznodziei, należał, podobnie jak Byczyna, Wołczyn, Namysłów i Oleśnica, do miejscowości, w których kultura i nauka stały na bardzo wysokim poziomie. Drukarnie w Brzegu, Oleśnicy, Wrocławiu działały prężnie, a szkolnictwo rozwijało się znakomicie, co przekładało się na intelektualny rozwój mieszCzaństwa śląskiego ${ }^{4}$.

Twórczość Gdacjusza określana jest mianem literatury kaznodziejsko-moralizatorskiej. Jan Zaremba wyodrębnia w tej materii trzy fazy: I (1674-1680) - w której powstają teksty o tendencji antyszlacheckiej, II (1681-1683) - kiedy to Gdacjusz tworzy pisma o tematyce moralnej, i III (1683-1688) - kiedy skupia się na tekstach o charakterze kościelnym i liturgicznym (ZAREMBA, 1969: 22). Analizowany Dyszkurs o grzechách szostego przykazánia Bożego... pochodzi z 1682 roku. Ta informacja występuje w tytule, który warto przytoczyć w całości ${ }^{5}$ : Dyszkurs O Grzechách Szostego Przykazania Bożego, jakoż to są: Cudzołóstwo, Wszeteczeństwo, Nieczystość, Nierzą etc., które Pismo zowie Uczynkami ciała (Galat. 5 v. 19). Sprawiony Przez Ks. Jadama Gdaciusa, Pastora Kluczborskiego. W Brzegu, Drukował Jan Krzysztof Jakub, Roku Pańskiego 1682. Barokowe nadużywanie wielkich liter w tytule jest typowe dla druków z wieku XVII ${ }^{6}$. Wzory drukarskie, także drukarni śląskich, opierały się na druku Biblii Gdańskiej z 1632 roku. Prace Gdacjusza były drukowane w czterech różnych

${ }^{3}$ Gdacjusz podkreślał bowiem: „[...] w Śląsku żyjąc, Ślężakom się akkommoduję: i mógłbym był tych i owych słów poniechać, gdybym zuyczaju w mówieniu w Śląsku naszym nie był upatrował" (z przedmowy do Postylli, cyt. za: Вокек, 1969: 101).

${ }^{4}$ Henryk Borek przytacza słowa Józefa Gierowskiego, który postrzega wielu śląskich pastorów jako ówczesną „inteligencję” pełniącą rolę nauczycieli, przyczyniającą się do rozwoju szkolnictwa, nauki i piśmiennictwa (BоRек, 1962: 6).

${ }_{5}$ Tytuł podaję $w$ transkrypcji dzisiejszej.

6 „Dużą literą pisano wszystkie rzeczowniki osobowe, nazwy o zabarwieniu emocjonalnym (Słowo Boże, Sakrament, Kościół itp.) oraz większość przymiotników dzierżawczych i przynależnościowych (w Kościele Ojczystym, w Polskim języku, Słowa Prorockie itp.)" (Borek, 1969: 91-92). 
drukarniach: u Michała Karnała w Toruniu, u Daniela Vetterusa w Lesznie, u Gotfryda Güncela w Oleśnicy oraz w Brzegu u Jana Krzysztofa Jakuba.

Gdacjusz jest postrzegany i określany jako przedstawiciel siedemnastowiecznej polszczyzny śląskiej i regionalnej, wykorzystujący w swoich tekstach bogatą gamę leksyki i paletę różnobarwnej frazeologii. Umiejętnie wplata w swoje utwory słowa oddające myśli, czasem niewygodne i uwierające odbiorcę, ale zawsze trafiające $w$ sedno, poruszające istotne problemy siedemnastowiecznych mieszkańców Śląska. Leksyka i frazeologia stanowią dla kluczborskiego „fararza” doskonałą broń w walce z niemoralnością, pijaństwem, nieobyczajnością i wszelkimi pokusami, z którymi ludzkość zmaga się od najdawniejszych czasów.

Badania nad twórczością i tekstami Gdacjusza były prowadzone od początku XX wieku. Zainicjował je Aleksander BrüCKNER (1903: 84-89), a kontynuowali Kazimierz Kolbuszewski (1921: 230-259), Wincenty Ogrodzińskı (1946: 65-67), Stanisław Rospond (1948: 101-105) oraz Henryk Borek (1962: 8), który jest autorem monografii o języku kluczborskiego kaznodziei. Współcześnie Izabela Kaczmarzyk opublikowała kilka prac poświęconych Gdacjuszowi i jego twórczości (m.in. KACzMARzYK, 2003). Brakuje jednak opracowań, w których poddawano by szczegółowej analizie wybrane utwory kluczborskiego „fararza”. Do tej pory badacze skupiali się na całościowym ujęciu jego twórczości, a nie na analizach poszczególnych tekstów. Brak także prac dotyczących leksyki i frazeologii wybranych utworów Gdacjusza, w szczególności popularnych dyszkursów. Warto zatem luki te uzupełnić.

Co decyduje o wyjątkowości i oryginalności tekstów tego protestanckiego kaznodziei, nazywanego śląskim Rejem? Dlaczego, mimo że nie jest uważany za czołowego reprezentanta polszczyzny literackiej XVII wieku, uchodzi za ważnego przedstawiciela piśmiennictwa regionalnego? W czym przejawia się odmienność jego stylu pisarskiego i co wyróżnia jego osobę na tle epoki? Na te pytania nie ma z pewnością jasnej odpowiedzi, ale analiza wybranego tekstu pozwoli, choć $w$ niewielkim stopniu, przybliżyć twórczość Gdacjusza oraz opisać stosowane przez niego słownictwo i frazeologię.

Analizie językowej i stylistycznej poddano Dyszkurs o grzechách szostego przykazánia Bożego... napisany przez kluczborskiego „fararza” w 1682 roku, wydany w Brzegu w drukarni Jana Krzysztofa Jakuba. Przebadane zostały leksyka i frazeologia związane z aktem seksualnym, pożądaniem, niemoralnością i grzechami wobec szóstego przykazania Dekalogu, z uwzględnieniem potocyzmów, a także leksyka związana z tym, co może nakłaniać do cudzołóstwa, jak na przykład wszelkiego rodzaju pokusy (materialne, cielesne), ale i zmysł wzroku, ponieważ za pomocą oczu dostarczane są człowiekowi bodźce wyzwalające między innymi pożądanie. Wybór taki podyktowany był funkcją, jaką pełnią przeanalizowane leksemy, frazeologizmy, potocyzmy oraz zbudowane z nich porzekadła i przysłowia w przywołanym dyszkursie. Z pozoru odległe semantycznie leksemy i frazeologizmy zostały wykorzystane do skonstruowania utworu poświęconego jednej tematyce: grzechowi cudzołóstwa. Gdacjusz za pomocą tak skomponowanego tekstu, używając kon-

${ }^{7}$ Korzystałam z przedruku tekstu Gdacjusza w transkrypcji, znajdującego się w zbiorze jego utworów opracowanym przez Borka i Zarembę (Bовек, ZARемBA, oprac., 1969: 365-391), oraz z tekstu oryginalnego, dostępnego w Dolnośląskiej Bibliotece Cyfrowej [online: http://www.dbc.wroc.pl/dlibra/ doccontent?id=24921 data dostępu: 12.08.2018]; zob. Źródła. 
kretnych leksemów (mimo wrażenia przypadkowości doboru) i połączeń wyrazowych, chce osiągnąć zamierzony cel - w dosadny i wyrazisty, niezwykle obrazowy sposób zwrócić uwage na problem cudzołóstwa i rozwiązłości, a co za tym idzie, nakłonić grzeszników do zmiany postępowania.

Borek w swojej pracy o języku Gdacjusza wyróżnia trzy zasadnicze warstwy stylistyczne, które można zauważyć $w$ tekstach kluczborskiego kaznodziei, a mianowicie: archaizmy, bodajże najbardziej charakterystyczne i często stosowane, regionalizmy (dialektyzmy) oraz elementy potocznego, spontanicznego, żywego języka, ale bez określonego podłoża gwarowego (BoreK, 1962: 9). Badacz zaznacza także, że twórczość Gdacjusza:

należy w całości do kręgu literatury kaznodziejskiej i moralizatorskiej, ponieważ to złoże stylistyczne, oparte głównie na tradycji XVI-wiecznej, miało największy wpływ na kształtowanie się języka u „fararza” kluczborskiego i przyjęte z tych tradycji środki tworzą podstawowy „kościec” stylistyczny w jego języku.

BOREK, 1962: 119

Bogusław Wyderka pisze zaś, że styl Gdacjusza czerpie z metod kaznodziejstwa średniowiecznego, o czym mogą świadczyć występujące w jego twórczości „fantastyczne egzempla i schematyczne rozumowanie, nawiązujące do metod scholastycznych" (WYDERKA, 1990: 34).

Kluczborski kaznodzieja doskonale znał i rozumiał polityczną, geograficzną, ale przede wszystkim językową peryferyczność Śląska. Izolacja społeczności śląskiej od polszczyzny ogólnej leżała mu na sercu. Jednym ze sposobów krzewienia i rozpowszechniania ogólnego języka polskiego było wspomniane już cytowanie oraz parafrazowanie czołowych polskich pisarzy czasów renesansu i wczesnego baroku. Szczególnie lubował się Gdacjusz w cytowaniu Mikołaja Reja i Jana Kochanowskiego. Jak pisze Borek, kaznodzieja kluczborski wyjątkowo upodobał sobie posługiwanie się wyrazami niecodziennymi, nieoczywistymi, bardzo rzadkimi, które możemy sklasyfikować jako neologizmy. Używał także archaizmów. Właśnie te leksemy, które w XVII wieku uchodziły za archaizmy, „istnieją po dziś dzień jako żywe elementy narzecza śląskiego" (BоReK, 1962: 122), a Gdacjusz, będąc świadomym użytkownikiem gwary śląskiej, nie unikał jej w swoich tekstach, a niekiedy celowo podkreślał - poprzez jej stosowanie - swoją więź z regionem, z którego pochodził i który kochał.

Analizowany Dyszkurs o grzechách szostego przykazánia Bożego... powstał w końcowej fazie twórczości kaznodziei, bo wydany był sześć lat przed jego śmiercią. Wpisuje się on w cały cykl kwestyji i dyszkursów, jakie w okresie od 1679 do 1688 roku wyszły spod pióra

${ }^{8}$ Borek pisał, że Gdacjusz ze szczególnym upodobaniem rozczytywał się w Kronice Marcina Kromera, przetłumaczonej przez Marcina Błażowskiego, i to z niej czerpał inspiracje do wplatania w swoje kazania wyrazów powszechnie nieznanych - tym bardziej, że, jak zauważa badacz, Kronika była bardzo popularna w XVII wieku, „ale chyba głównie ze względu na język Błażowskiego, bardzo dostojny i oryginalny, naszpikowany niezliczonymi neologizmami tłumacza" (ВоRек, ZAREмBA, oprac., 1969: 120). 
Gdacjusza ${ }^{9}$. To, jak rozumie on dyszkurs ${ }^{10}$, wyjaśnia w przedmowie do Dyszkursu o dobrych uczynkach... Pisze tam: „Chcąc prowadzić dyszkurs [...] niektóre nader potrzebne i poważne kwestyje w nich roztrząsać będziemy” (cyt. za: KAсzMARzYK, 2003: 122). W omawianym utworze, podobnie jak i w pozostałych tego typu, można zauważyć pewien określony porządek kompozycyjny. Kaczmarzyk pisze:

Formuły tytułowe są zawsze dwuczłonowe. Pierwszy człon to kwalifikacja gatunkowa, rozpoczynająca się od charakterystycznego wyrażenia „kwestyja o...”, „dyszkurs o...", człon drugi natomiast stanowi rodzaj dookreślenia problemu, pełniąc rolę swoistego podtytułu.

KACZMARZYK, 2003: 123

W przypadku wszystkich dyszkursów dookreślenie wyrażone jest $w$ formie zdania twierdzącego i stanowi jednocześnie swego rodzaju wyjaśnienie (KACzMARzYK, 2003: 124). Tak też jest $w$ przypadku omawianego tekstu: „[...] jákoż to są: cudzołostwo, wszeteczeństwo, nieczystość, nierząd etc., ktore Pismo zowie uczynkámi ciáła (Galat. 5 v. 19)". Jacek i Stanisław Kolbuszewscy piszą o konstrukcji omawianego dyskursu tak:

[...] wywody o szkodliwości, argumentacja popierana przykładami zmierzającymi do wywołania lęku, dorzucanie przykładów pojętych jako wzory pozytywne, godne naśladowania, cytacje „uczone”, nawoływania do poprawy i znowu przywiedzenie na pamięć czekającej za grzechy kary potępienia wiecznego.

Kolbuszewscy, 1964: 21

Leksyka i frazeologia, która występuje w omawianym dyszkursie, charakteryzuje się ogromną ekspresywnością, obrazowością i różnorodnością. Gdacjusz, znany z gwałtownego stylu wypowiedzi i dosadności, dobierając słowa, stara się osiągnąć efekt piorunujący,

${ }^{9}$ Gdacjusz, oprócz omawianego Dyszkursu o grzechách szostego przykazánia... (1682), opublikował następujące kwestyje i dyszkursy: O pańskim i szlacheckim albo rycerskim stanie dyszkurs... (1679); Appendin, tj. przydatek do dyszkursu o pańskim i szlacheckim albo rycerskim stanie dyszkurs... (1681); Dyszkurs o pijaństwie... (1681); Dyszkurs o pijaństwie kontynuacyja... (1682); Kontynuacyja albo kończenie dyszkursu o grzechach szostego przykazánia... (1682); Kwestyja o zmartwychwstaniu... (1683); Kwestyja o poligamijej albo wielożeństwie... (1683); Kwestyja o pojedynkach... (1684); Kwestyjej o pojedynkach... kontynuacyja (1684); Kwestyja jeśli Maryja Najświętsza może i ma być nazwana Panna?? (1685); Dyszkurs o Pannie Maryjej, krzyżach i krucyfiksach (1686); Trojaki o ołtarzach, obrazach i organach dyszkurs... (1688). Pełną bibliografię utworów kluczborskiego pisarza podaje Borek (BoREK, ZAREMBA, oprac., 1969: 111-114).

10 Starożytny discursus charakteryzował się określonym porządkiem retorycznym. Wywód dotyczący obranego problemu czy też zagadnienia rozpoczynał się wprowadzeniem (erordium). Po nim następowało zaprezentowanie tego, co będzie omawiane (propositio), a następnie ekspozycja tegoż problemu, połączona z przedstawieniem faktów (narratio), która poprzedzała zbiór argumentów świadczących o ich prawdziwości (confirmatio). Potem miała miejsce polemiczna część dyskursu, konfrontująca prezentowane poglądy z poglądami przeciwnika, co miało doprowadzić do zbicia jego dowodów (refutatio), a w rezultacie zamknąć całość wywodu trafną konkluzją (peroratio) (KolBuSZEWSCY, 1964: 18). 
porażający słuchaczy całą siłą przekazu. Taki zamiar wiąże się także z częstymi powtórzeniami, pewnego rodzaju redundancją szczególnie w zakresie egzemplów. Co istotne, Gdacjusz najczęściej przywołuje przykłady o wydźwięku negatywnym, pomija zaś pozytywne świadectwa trwania $w$ boskich przykazaniach lub pisze o nich sporadycznie: „wydobywa tylko cienie i błędy, przestępstwa i występki, ale giną $w$ nim z natury rzeczy zjawiska dodatnie. Mówił o nich, wysuwał je jako antytezę tamtych" (Kolbuszewscr, 1964: 22).

Gdacjusz w przywołanym dyszkursie stosuje różnorakie określenia obcowania płciowego, nie tylko kobiety z mężczyzną - porusza także problem homoseksualizmu. Opisom aktu płciowego towarzyszy dobór wielu czasowników, fraz, wyrażeń i połączeń wyrazowych, które obrazowo nakreślają omawiany w kazaniu problem. Wszelkie pozamałżeńskie kontakty seksualne, ostro potępiane z kluczborskiej ambony, opisuje Gdacjusz za pomocą następujących leksemów i połączeń wyrazowych: broić, sprawę mieć, bawić się, mieć (łaczenie), płodzić (nierzq̨), poniewolić (do wszetecznego uczynku), uczynić dosyć (żądności), cudzołożyć, parać się (nieczystościa), podawać (ciało), dziać (nierzad), obcować, spać, bywać z kimś, schadzać się, spółkować. Taka rozmaitość leksykalna wprowadza dynamizm w poszczególne partie tekstu oraz zapobiega przewidywalności i monotonii. Aby wiernie oddać funkcję i znaczenie wspomnianych wcześniej czasowników, warto przywołać ich użycie w kontekście: „Jął ją jáwnie bronić z náłożnictwá, które z cesárzem broiłá (s. 373)”"11; „[...] kiedy to z bestyją álbo z bydlęciem jáko z niewiástą álbo z mężem spráwę ma [...]” (s. 375); „[...] ktorzy się nieczystością i nierządem bawili” (s. 377); „W tymże mieście (Koryncie) báwiłá się jákaś záwołana wszetecznica Lais, ktora od Demosthenesa dziesięć tysięcy dragm (poczwornych groszow) zá jedno łączenie żądáłá” (s. 378); „[...] im wolno było według upodobánia nierząd (niecnotę) płodzić [...]” (s. 378); „[...] żoná Potyfárowá chciáłá cnotliwego i wstydliwego młodzieńcá Józefá do wszetecznego uczynku poniewolić" (s. 378); „Uczynięć ja dosyć żądności twojej [...]” (s. 379); „Ergo i mnie wolno cudzołożyć i nierządu patrzyć” (s. 379); „Ták i wy, co się nieczystotą paracie [...]” (s. 379); „[...] ciáło swoje ná wszeteczeństwo i nieczystość podáje [...]” (s. 380); „[...] się wszeteczeństwo (nierząd, nieczystość) i cudzołostwo dzieje ná ciele [...]” (s. 380); „[...] z człowiekiem po wszystkim ciele trądem jádowitym zárażonym obcował [...]” (s. 380); „[...] przez niemáły czás nieczystość z nim płodził [...]” (s. 386); „[...] że się nieczystej miłości uwieść dáłá [...]” (s. 386); „[...] spał z nią (bywał z nią, álbo się gdzie osobno z nią był schadzáć miał)” (s. 389); „[...] z nierządnicámi społkujesz i z nimi się włoczysz [...]” (s. 382).

Gdacjusz w swoim dyszkursie wylicza także różnorakie przyczyny nierządu, ulegania grzechowi wszeteczeństwa i niemoralnego prowadzenia się. Wiele rzeczy, nie zawsze oczywistych, może przyczynić się do wstąpienia na złą drogę. Kluczborski kaznodzieja przyczynę popełnienia grzechu widzi w takich czynnikach, jak: 1) stroje i ozdoby: „Podnietá do nieczystości jest Ornatus álbo stroje" (s. 387), 2) piosenki frantowskie: (nierządnicze): "Amatorii cantus: frántowskie (nierządnicze) piosenki i te częstokroć pobudką bywáją do nieczystości [...]” (s. 388), 3) niewiasty: „Kiedy kto z białymi głowámi rad schadzki miewa i z nimi się kuma, tedy przez to łatwie nierządną (wszeteczną) miłością przeciwko nim zápalić się może” (s. 388), „[...] bo z száty pochodzi mol, á z niewiásty wiele złego” (s. 388),

11 Numery stron odwołują się do tekstu Gdacjusza przedrukowanego i opracowanego przez BorkA i ZAREMBE (1969). 
4) rozmowy: „Colloquia: rozmowy przywodzą wielu do nierządu. Gdy owo kto rad z białą płcią rozmawia, łatwie przez tákie rozmowy serce zránione i do nieczystości zápalone być może” (s. 389), 5) taniec: „[...] ták i lekkomyślny tániec bywa częstokroć przyczyną i powodem do nieczystości i inszych grzechów” (s. 389), czy wreszcie 6) pijaństwo: „Ebrietas: opilstwo. I toć człowieká podżega (poduszcza) do wszeteczeństwa [...]” (s. 390), a nieco dalej: „Dobrzy pijacy są wielcy cudzołożnicy (wszetecznicy)” (s. 390).

U kluczborskiego „fararza” także oczy oraz funkcja, jaką pełnią, zdają się jedną z przyczyn rozwiązłości i grzechu nieczystości, gdyż dostarczają bodźców wyzwalających w określonych sytuacjach pociąg seksualny, pożądanie czy też pragnienie bliskości cielesnej. Dlatego $w$ omawianym tekście motyw oczu jako narzędzia grzechu występuje często. Kaznodzieja z Kluczborka przestrzega przed niewiastami, które „psu oczy przedawszy [...], nierządu pátrzą" (s. 384), a „i w kościele oczy wszeteczne miewają [...]” (s. 387). Także młodzieńcy i mężczyźni nie pozostają bez winy, dlatego i o nich Gdacjusz pisze: „[...] do kościołá wchodząc oczy w nię wlepił, álbo wytrzeszczywszy oczy, chciwie ná nię patrzył” (s. 387). Przestrzega ich przed kobietami, które celowo ubierają się do kościoła tak, aby „ná piękne (stroje) młodzieńce świdrzącymi oczyma poglądały” (s. 387), a przecież „w kościele ná białe głowy nieczystym nie godzi pátrzyć okiem" (s. 387). Gdacjusz wplata w swój tekst swoiste powiedzenia i mądrości, które niosą z sobą wciąż te same treści. Takie kluczenie wokół tematu, wielokrotne powracanie do sedna problemu ma sprawić, że zapadnie on słuchaczom $w$ pamięć i skutecznie odwiedzie ich od popełniania niemoralnych czynów. Kluczborski „fararz” pisze: „[...] nieczyste oko jest nieczystego sercá posłem” (s. 387) albo: „[...] nie mówcie, że macie sercá czyste, jeśli macie oczy nieczyste” (s. 387).

Jednakże nie zawsze oczy to przyczyna złego. Gdacjusz w jednym z fragmentów swojego kazania pisze: „Oczy są w miłości wodzámi, álbo, z pátrzánia pochodzi miłość” (s. 386). Warto zwrócić także uwagę na dobór przymiotników oraz czasowników wykorzystywanych przez Gdacjusza do konstrukcji zdań, w których występuje leksem oko. Oczy mogą być nierzadne, nieczyste, wszeteczne czy świdrzace, a można nimi przedawać, rzucać, grać, poglądać, patrzeć, a także je wytrzeszczać, wlepiać, miewać, wydrapać, wyklwać. Leksem wyklwać stanowi formę wyrazu wykalać. Właśnie w takiej postaci - wyklwać - jest on notowany $w$ dziele Grzegorza Knapiusza pt. Thesaurus polono-latino-graecus seu promptuarium lingua Latinae et Graece [...] (SKnap), wydanym w Krakowie w 1621 roku. Jak wiadomo, Gdacjusz znał Thesaurus i czytywał go. Leksemowi wyklwać poświęcono odrębny artykuł hasłowy $w$ słowniku Knapiusza, w którym podano przykład użycia tegoż wyrazu w języku polskim: „Wyklwał kur kurowi oko” (SKnap). Leksem ten jest notowany także ponad sto lat później, w Nowym dykcjonarzu, to jest Mowniku polsko-niemiecko-francuskim Michała Abrahama Trotza (STr), wydanym w Lipsku w 1764 roku. Tu autor umieszcza leksem wyklwać w obrębie hasła wykalać, wykalam w podhaśle wykalam, któremu przypisane jest znaczenie 'wykluję, wykluć' i podaje przykład użycia: „Kur kurowi wyklwał (wykluł) oko” (STr). W tekście Gdacjusza występuje on w zdaniu: „Widząc to bocian ná onego niewdzięcznego sługę uderzył i wyklwał albo wydrapał mu oczy, áby się krzywdy, ktora się pánu jego nieprzytomnemu stáłá, pomścił" (s. 371). Borek w swojej monografii o języku Gdacjusza nie notuje tego leksemu.

Bardzo barwnie prezentują się dosadne frazeologizmy oraz wszelkie potocyzmy, które dodają ekspresji i autentyczności wypowiedzi kluczborskiego „fararza”, stylizując ją na swo- 
isty dialog z potencjalnym odbiorcą, słuchaczem. Gdacjusz zdaje się ważyć słowa, dobierając je starannie, zgodnie z wykładnikami stylu kaznodziejskiego, ale kiedy emocje biorą górę, sięga po słownictwo potoczne, czasami grubiańskie, tak różne od przywoływanych biblijnych przypowieści czy licznych cytatów z pism św. Augustyna. Owa dosadność ma wstrząsnąć słuchaczem i czytelnikiem, unaocznić mu popełniany błąd, porazić obrazowością i nawrócić na drogę prowadzącą do zbawienia. Kaznodzieja zwraca się do panien i młodzieńców, mówiąc:

Jeśli tedy ty, młodzianie, w młodzieńskim stanie twoim z nierządnicámi społkujesz i z nimi się włoczysz jáko pies z kością, á ty, pánno, jeśli czystości pánieńskiej w cále nie záchowujesz, wianek wprawdzie ná łbie nosisz, áleś już dawno ná czepek zárobiłá i dawno w tobie (w ciele twoim) czystość pánieńska wywietrzała, coż stąd mieć będziesz?

Przywołane frazeologizmy włóczyć się jako pies z kością oraz nosić na łbie wianek są osadzone $w$ siedemnastowiecznych realiach śląskich. Nie brak i humoru - mocno podszytego zjadliwą ironią - $w$ dalszej części przywołanej wypowiedzi: „wianek wprawdzie ná łbie nosisz, áleś już dawno ná czepek zarobiła".

Gdacjusz wykorzystał liczne frazeologizmy zbudowane z użyciem wyrazów potocznych, aby skutecznie dotrzeć do odbiorcy i zwrócić jego uwagę na problem wszeteczeństwa i cudzołóstwa. Warto przywołać niektóre z nich: stulić gębę ('milczeć’): „I ták gębę stuli, mię i cesárzá więcej karáć nie będzie” (s. 374); wlepić w kogoś oczy ("patrzeć się na kogoś uporczywie'): „Jeden z nich, widząc jákąś nadobną i rodu zacnego pánnę do kościołá wchodzącą, oczy w nię wlepił, álbo wytrzeszczyuszy oczy, chciwie ná nię pátrzył" (s. 387). Oprócz typowych frazeologizmów notowanych w słownikach szesnasto- i siedemnastowiecznej polszczyzny, a także będących jeszcze dziś w użyciu, stosuje Gdacjusz zwroty mniej znane, ale pretendujące do miana stałych połączeń wyrazowych, na przykład ostydna komuś nogi ('ktoś umrze'): „Drugi ledwie żonie nogi ostydną i ledwie ciáło jej z domu wyniosą, aż ci o inszej myśli" (s. 382) ${ }^{12}$; kumać się z kimś ('zadawać się z kimś, zawrzeć z kimś bliższą znajomość'): „Kiedy kto z białymi głowámi rad schadzki miewa i z nimi się kuma, tedy przez to łatwie nierządną (wszeteczną) miłością przeciwko nim zápalić się może" (s. 388); lizać się z kimś13 ('przen. całować się z kimś'): „[...] wdowy [...] po śmierci małżonków swoich zálety odpráwują, bánkietują, táńczą, z chłopy się liżą i są ták płoche, zuchwáłe i lekkomyślne, że wnet mężów swych zmarłych zápomináją" (s. 382); mieć kogo w pomietlech ("pogardzać kimś, lekceważyć kogoś’): „Nie wiem, ále to wiem, że druga májąc mężá swego w pomietlech, bryżuje się kwoli inszym chłopom i gálántom, z którymi więc nierządu po kryjomie pátrzy" (s. 388). Jeszcze Słownik języka polskiego Samuela Bogumiła Lindego (SL) notuje to określenie, podając za przykład słowa Fabiana Birkowskiego: „Magistrat każdy u was w po-

${ }^{12}$ Wyraz ostydnąć jest do dziś używany w gwarze śląskiej w znaczeniu 'ostygnąć, oziębnąć, wystygnąć'.

${ }^{13}$ W kartotece Słownika gwar śląskich pod redakcją Wyderki występuje czasownik lizać się w znaczeniu przenośnym 'całować się z kimś'. Notowanie pochodzi z miejscowości Złotniki w powiecie opolskim. 
mietlech” i Wacława Potockiego: „Z tą pretensyą zostaniesz w pomietle”. Warto zwrócić uwagę także na przywołany już wcześniej frazeologizm przedać psu oczy ('pozbyć się wstydu, zachowywać się bezwstydnie'): „psu oczy przedawszy [...], nierządu pátrzą” (s. 384). Notuje go Borek w swojej pracy o języku Gdacjusza, wyjaśniając, że znaczy on 'stracić wstyd, sumienie' (BоREK, 1962: 161). Badacz cytuje także przykład z użyciem tegoż zwrotu, zamieszczony w słowniku Lindego: „Psu oczy przedał, a czartowi duszę (Jabłonowski)” (BoREK, 1962: 161), zaznaczając, że prawdopodobnie był to wówczas zwrot popularny. Słowniki Trotza i Knapiusza, choć bliższe czasom Gdacjusza, nie zawierają tego frazeologizmu w obrębie artykułu hasłowego przedawać. Gdzie indziej kaznodzieja kluczborski używa zwrotu stulić gębę ('zamilknąć, nie odzywać się'): „I ták gębę stuli, mię i cesárza więcej karáć nie będzie" (s. 374). Jest to zwrot potoczny, wymowny, powszechnie używany, wzięty z mowy żywej, nacechowany ekspresywnością. Słownik Trotza notuje w obrębie artykułu hasłowego stulam powiedzenie: stulić gębę, oczy, podając przykład użycia „stul gębę, albo weźmiesz w nię" (STr). Także i Knapiusz przywołuje powiedzenie: stulam gębę, oczy (SKnap). Inny przykład wykorzystania przez Gdacjusza frazeologizmu to stawić coś na szańc ('wystawić na niebezpieczeństwo'): „Zuzánná, oná pobożna i czysta mátroná, woláłá zdrowie swe w niebezpieczeństwo podáć i ná száńc stáwić, ániżeliby się byłá miáłá cudzołostwá dopuścić i zmázáć nieczystością czyste łoże mężá swego" (s. 378-379). Trotz przytacza leksem szańc oraz frazeologizm na szańc nieść, wydawać wraz z przykładem użycia: „nieść na szańc głowę; sławę, życie” (STr), podobnie jak Linde, który pisze: „Na szańc stawić, kłaść, nieść, = narażać, wystawiać na niebezpieczny raz, ryzykować" (SL). Borek zauważa, że ów frazeologizm należy do niezbyt popularnych w XVII wieku, a nawet postrzega go jako archaiczny, nawiązujący do tradycji stylu biblijnego lub kaznodziejskiego (BorEK, 1962: 168).

Wyodrębnione i zacytowane przykłady doskonale oddają sugestywność i barwność języka Gdacjusza. Konstrukcje wyrazowe zbudowane z użyciem przywołanych wyrazów Borek nazywa zwrotami metaforycznymi lub metonimicznymi, które charakteryzują się silną obrazowością i dosadnością, a co za tym idzie - dużym nacechowaniem stylistycznym (BOREK, 1962: 168).

W analizowanym dyszkursie nie brak i przysłów, które Gdacjusz tak chętnie i często stosuje. Odwołując się do tych zaczerpniętych z pism różnorakich autorów, zazwyczaj podaje je $w$ oryginalnym zapisie i wplata w wywód, który prowadzi. Najczęściej cytuje przysłowia $w$ języku łacińskim¹4, czasami niemieckim, zawsze podając ich tłumaczenie lub parafrazując ich treść:

Qui virginem invenire desiderat, ipse ad nuptias virgo sit: intactam quaeris, intactus esto, mówi Augustyn ś.: „Kto czystą pánnę náleźć prágnie, niechże sam aż do wesela czystą pánną będzie: szukasz niepokalánej (nienáruszonej), bądźże sam niepokalány (nienáruszony)".

14 Kinga Титак (2012: 84) w swoim artykule odwołuje się do słów Stefanii Skwarczyńskiej, która tak oto wyjaśnia zasadność przywoływania latynizmów w tekstach polskich: „Użycie latynizmów jest podporządkowane innemu celowi, mianowicie potrzebie wyrażania pojęć określeniami im tylko właściwymi, pragnieniu, by pewnym treściom intencjonalnym służyły im tylko przynależne wyrazy, słowem pragnieniu jednoznaczności i związanej z tym potrzeby ścisłości" (SKWARCZYŃSKA, 1937: 359). 
„Fararz” z Kluczborka w omawianym dyszkursie pisze: „Wstyd (czystość) nie szátá zdobi” (s. 388), przestrzegając tym samym przed zbytnim przywiązywaniem wagi do stroju i przesadnym dbaniem o siebie. Pisze dalej: „A nie dlategoć száty nosiemy, ábyśmy drugich do siebie wabili, ále sromotę nászę nimi nákrywáli: sunt enim velamenta pudoris, signa reatus: "száty są zasłoną wstydu, á znákiem obwinieniá «" (s. 388). Przywołane fragmenty to mądrości, którymi dzieli się Gdacjusz ze swoimi odbiorcami. W bezpośredni, niepozostawiający złudzeń sposób wyjaśnia i przestrzega przed grzechem tych, którzy wygląd zewnętrzny postrzegają jako niezwykle ważny element ludzkiej egzystencji.

Analizowany Dyszkurs o grzechách szostego przykazánia Bożego... realizuje - jak można sądzić - wyznaczniki stylu kaznodziejskiego. Jednak, jak pisze Borek, „niektóre fragmenty jego utworów więcej przypominają realistyczną twórczość mieszczańskiej literatury sowizdrzalskiej niż tradycyjny styl kaznodziejski" (BоREK, 1962: 180). Wynikać to może z faktu, że kluczborski „fararz” adresował swoje kazania, a także i teksty, do ludzi prostych, nieprzywykłych do wyszukanych leksemów i wzniosłych treści. Jak się zdaje, doskonale jednak potrafił łączyć te dwie rzeczy. Liczne odwołania do Biblii, pism św. Augustyna oraz czołowych twórców polskiego renesansu i baroku (niekiedy zbyt liczne), gdzie dominuje styl podniosły, a ton wypowiedzi jest patetyczny, współgrają z dosadnym i momentami grubiańskim językiem Gdacjusza. Obok przypowieści i przykładów biblijnych wybrzmiewają w dyszkursie anegdoty i dykteryjki zaczerpnięte z życia codziennego, znane każdemu, kto owych „niewygodnych dla ucha” opowieści słucha lub je czyta. Gdacjusz nie przedkłada wyznaczników stylu nad efekty, jakie może przynieść mowa żywa, pełna ekspresji i wyrazistości, przepełniona niekiedy pretensjami, groźbami i gromkimi wyrzutami skierowanymi $w$ stronę wiernych. Dlatego tak wiele $w$ jego dyszkursie frazeologizmów zaczerpniętych wprost z żywej mowy prostych ludzi. Żeby bowiem dotrzeć do ich serc i umysłów, trzeba mówić do nich tym samym językiem, którym się posługują. Poprzez takie zabiegi stylistyczne Gdacjusz nie realizuje $w$ pełni w swoim tekście wyznaczników stylu wysokiego czy kaznodziejskiego, nie oznacza to jednak, że ów tekst nosi cechy stylu potocznego. Jak już zostało wspomniane, wtręty łacińskie i cytaty z Biblii powodują, że zaczyna on przypominać zlepek kilku stylów, co wydaje się niekiedy zbyt przytłaczające dla przeciętnego odbiorcy ${ }^{15}$.

W tekstach Gdacjusza dominują wyrazy potoczne, znane i używane przez ówczesnych mieszkańców Kluczborka i okolic oraz samego autora kazań. Wiele z tych leksemów przetrwało $w$ niezmienionej formie do dziś i nadal funkcjonuje, chociażby $w$ gwarze śląskiej, ale, jak pisze Borek: „[...] musimy być ostrożni przy kwalifikowaniu tych form jako gwarowych już $w$ XVII w., aby nie popaść $w$ anachroniczne przenoszenie dzisiejszych kryteriów na interesujący nas wiek XVII [...]" (BоREK, 1969: 102). Można jednak wskazane wyrazy określić mianem potocznych w czasach współczesnych Gdacjuszowi. Oto przykłady: dawić ('dusić, dławić’): „[...] że ci z kościołá mieli być wyrzuceni (wyklęci, wyłączeni), którzy by rzeczy dawione (zájące álbo ptaki w sidłách albo w sieciách zádawione) i pokármy ze krwią bydlęcą przygotowáne [...] jadáli" (s. 370); inedy/inegdy ("kiedy indziej, w innym

15 Borek pisze: „Utwory Gdaciusa są więc w sumie bardzo nierówne: miejscami ciężkie, przeładowane cytatami, »niestrawne«, miejscami natomiast obrazowe, sugestywne, pulsujące życiem. Nie ulega jednak wątpliwości, że »fararz« kluczborski jest wyraźnie zarysowaną indywidualnością, a jego odrębność językowo-stylistyczna narzuca się każdemu, kto bliżej poznał jego twórczość" (BorEK, 1962: 182). 
czasie'): „A ten grzech słusznie zá cięższy miány álbo poczytány być ma niż wszeteczeństwo i cudzołostwo, o czym się inedy nieco więcej powie” (s. 375); „[...] że nieczystość jest grzechem náder wielkim, dla którego Bog, o czym się inegdy nieco szerzej powie, ludzi surowo karze” (s. 379); po lekku/polekku (‘powoli'): „[...] tedy jednák po lekku (powoli) już od kilkuset lat jeden kościół po drugim tego postánowienia Apostolskiego nie przestrzegał [...]” (s. 370); kąszczek/kąsek ('trochę'): „[...] i tego kąská chlebá, ktory do gęby niesie [...]” (s. 367); jucha ('krew'): „[...] (co łácinicy edulium ex sangvine factum, my to czarną juchą zowiemy)" (s. 370). Należy zaznaczyć, że wymienione formy to wyrazy staropolskie używane jeszcze $w$ XVI wieku, ale $w$ kolejnym stuleciu postrzegane już jako wychodzące z użycia i archaiczne ${ }^{16}$.

Analiza Dyszkursu o grzechách szostego przykazánia Bożego... pokazała, że z doboru osobliwej leksyki i frazeologii, która czyni wypowiedź Gdacjusza autentyczną i ekspresyjną, wypływa oryginalność jego stylu. Mimo że pełnił funkcję pastora, nie przywiązywał dużej wagi do tego, że czegoś nie wypada mówić lub należałoby to powiedzieć w inny, subtelniejszy sposób. Gromiąc i nawracając wiernych, łączył w swoim wywodzie oraz argumentacji różnorakie sprzeczności, szczególnie na poziomie leksyki. Cechą charakterystyczną analizowanego dyszkursu jest zestawienie potocznych form wyrazowych i dosadnych frazeologizmów z formami rzadkimi i niekiedy archaicznymi. Mogło to wynikać zarówno z temperamentu kluczborskiego „fararza”, jak i z oryginalnej, przemyślanej koncepcji pisarskiej, indywidualnego stylu oraz świadomości, że jego odbiorcami będą prości czytelnicy śląscy. Dyszkurs o grzechách szostego przykazánia Bożego... doskonale ukazuje, w jaki sposób Gdacjusz kompiluje i miesza z sobą skrajności (leksykalne i stylistyczne), osiągając dzięki temu zaskakujący i oryginalny wykład.

\section{Źródła}

Gdacjusz A.: Dyszkurs o grzechách szostego przykazánia Bożego... [Brzeg 1682]. W: BoreK H., ZAremba J., oprac.: Adam Gdacjusz. Wybór pism. Warszawa-Wrocław 1969, s. 365-391.

Gdacjusz A.: Dyszkurs o grzechách szostego przykazánia Bożego... [online: http://www.dbc.wroc.pl/ dlibra/doccontent?id=24921; data dostępu: 1.08.2018].

\section{Słowniki}

SKnap - KNAPIUSz G., 1621: Thesaurus polono-latino-graecus seu promptuarium lingua Latinae et Graece [...]. Kraków [online: http://www.wbc.poznan.pl/dlibra/doccontent?id=104808; data dostępu: 13.08.2018].

SL - Linde S.B., 1807-1814: Słownik języka polskiego. T. 1-6. Warszawa [online: http://kpbc.umk.pl/ publication/8173; data dostępu: 20.08.2018].

16 Borek zuraca uwagę na to, że „Formy te notują z reguły ówczesne słowniki śląskie (Kuschius, Ernesti), natomiast u innych pisarzy XVII-wiecznych nie spotykamy ich prawie wcale, a Thesaurus Knapskiego czy gramatyka Wojny opatrują je swoimi kwalifikatorami jako rzadkie lub nieużywane. Przekształciły się one z wolna z dawnych archaizmów w nowe dialektyzmy" (BorEK, 1969: 102). 
STr - Trotz M.A., 1764: Nowy dykcjonarz, to jest Mownik polsko-niemiecko-francuski [...]. Lipsk [online: https://www.dbc.wroc.pl/dlibra/publication/7823/edition/7138/content; data dostępu: 13.08.2018].

WYDERKA B., red., 2000-2017: Słownik gwar śląskich. T. 1-16. Opole.

\section{Literatura}

Borek H., 1962: Język Adama Gdaciusa. Przyczynek do dziejów polszczyzny śląskiej. Wrocław-Warszawa-Kraków.

Borek H., 1969: Uwagi o jezzyku. W: Borek H., Zaremba J., oprac.: Adam Gdacjusz. Wybór pism. Warszawa-Wrocław, s. 87-110.

Borek H., Zaremba J., oprac., 1969: Adam Gdacjusz. Wybór pism. Warszawa-Wrocław.

Brückner A., 1903: Przyczynki do słownictwa polskiego. Kraków [online: https://polona.pl/item/ przyczynki-do-slownictwa-polskiego,MTEzMTkyNA/2\#into:metadata; data dostępu: 27.09.2018].

Kaczmarzyк I., 2003: Adam Gdacjusz. Z dziejów kaznodziejstwa śląskiego. Katowice.

Kolbuszewscy J. i S., 1964: Adam Gdacjusz i jego warsztat pisarski w świetle kazań i dyszkursów. „Kwartalnik Opolski” X, z. 1, s. 3-29.

KolbuszewsKI K., 1921: Postyllografia polska XVI i XVII wieku. Kraków.

OGRodzı́́SKı W., 1946: Dzieje piśmiennictwa śląskiego. Katowice-Wrocław.

Rospond S., 1948: Zabytki języka polskiego na Śląsku. Wrocław.

SKWARCZYŃSKA S., 1937: Estetyka makaronizmu (próba postawienia zagadnienia). W: Z zagadnień poetyk. Nr 6: Prace ofiarowane Kazimierzowi Wóycickiemu. Wilno-Warszawa, s. 337-370.

ТитАк K., 2012: O sposobach zapisywania wyrazów zapożyczonych w drukach XVI i XVII wieku - na przykładzie rzeczowników kwestia i dyskurs. „LingVaria” VII, nr 2 (14), s. 77-87.

WYDERKA B., 1990: Cechy składniowo-stylistyczne siedemnastowiecznej prozy publicystycznej. Piśmiennictwo śląskie na tle ogólnopolskim. Opole.

Zaremba J., 1969: Życie i dzieło Adama Gdacjusza. W: Borek H., Zaremba J., oprac.: Adam Gdacjusz. Wybór pism. Warszawa-Wrocław, s. 7-86.

Agata Haas

On Lexis and Phraseology in Adam Gdacjusz' Dyszkurs o grzechách szostego przykazánia Bożego...

Summary

The article analyses the vocabulary and phraseology of Dyszkurs o grzechách szostego przykazánia Bożego... written by Adam Gdacjusz, the Kluczbork clergyman. The tert was published in 1682 in Jan Krzysztof Jakub's printing press in Brzeg. Gdacjusz is qualified as the $17^{\text {th }}$ century representative of the Silesian Polish. In this particular text he writes about the issue of promiscuity, adultery and sinuous conduct.

The lenis and phraseology of the Dyszkurs... is characterised by explicit expressiveness, vividness and diversity. The author is known for his rapid style of rhetoric and crudeness that he achieves by the careful selection of words, with which he strikes the reader emphasising the brutal power hidden 
within them. Such a method requires frequent repetitions, rehashes, and a peculiar kind of redundancy, especially in the case of exempla. The text surprises the reader with the multitude of names associated with human serual life. Gdacjusz enumerates and discusses the reasons for prostitution, yielding to the sin of dissoluteness, and immoral conduct. The colourfulness and vividness of the Kluczbork preacher's text is also influenced by the various idiomatic expressions, sayings, proverbs and numerous colloquialisms taken directly from the language spoken by the Kluczbork dwellers of that time. Lexis built in this way adds authenticity and expression to his deliverance. What is important, some words and idioms still function today. In his sermons, Gdacjusz both fulfils the requirements of the preacher's rhetoric and links simplicity with sophistication on the lexical layer. A sublime and elevated style of his utterance interweaves with the sharp, plain, and sometimes even coarse tone of preaching. Therefore, Adam Gdacjusz' oeuure stands out from other Silesian preachers and contributes significantly to the $17^{\text {th }}$-century Silesian Protestant literature. 